Удк 618.146-006.6:615.28

DOI 10.11603/2414-4533.2016.3.6809

(С В. Г. ДУБІНІНА, О. В. ЛУК'ЯНЧУК, А. О. ПАЦКОВ

Одеський національний медичний університет,

Центр реконструктивної та відновної медицини Одеського національного медичного університету

\title{
Персоніфікований підхід до ведення паціенток з місцево поширеним раком шийки матки
}

\author{
V. H. DUBININA, O. V. LUKYANCHUK, A. O. PATSKOV
}

Odesa National Medical University,

Center of Reconstructive and Restorative Medicine of ONMU, Odesa, Ukraine

\section{THE PERSONALIZED APPROACH TO CARRY OUT PATIENTS WITH LOCALLY COMMON CERVICAL CANCER}

У даній статті, rрунтуючись на власному клінічному досвіді (Університетська клініка Одеського національного медичного університету), запропоновано тактику ведення пацієнток з місцево поширеним раком шийки матки, ускладненим кровотечею, i, як наслідок, неможливістю надання спеціального лікування. Використовували такі малоінвазивні методики, як лапароскопія та емболізація внутрішніх клубових артерій, як підготовчий етап перед спеціальним лікуванням.

In this article, based on their own clinical experience (University Clinic of Odesa National Medical University) the authors proposed tactics with locally advanced cervical cancer patients, complicated by bleeding and, as a consequence, not the possibility of providing special treatment. We used non-invasive techniques such as laparoscopy and embolization of the internal iliac arteries, as a preparatory stage before a special treatment.

У світі рак шийки матки (РШМ) залишається однією 3 найбільш поширених форм злоякісних новоутворень, займаючи 2-ге місце за частотою i 3-тє за смертністю серед усіх онкологічних захворювань у жінок. Захворюваність на РШМ за останні роки залишається стабільно високою і не має тенденції до зниження. У 2014 році захворіла 4101 жінка, з них майже 60 \% працездатного віку. Показники смертності від раку шийки матки в Україні в 2014 році склали 9,3 на 100000 населення [1, 2]. Світовий досвід показав, що рання діагностика початкових форм раку шийки матки дійсно сприяє зниженню захворюваності та смертності. Регулярне проведення цитологічного скринінгу може зменшити кількість випадків раку шийки матки на 80 \%. [3] Але, незважаючи на досягнуті успіхи в діагностиці РШМ, в даний час значна кількість жінок звертається за медичною допомогою вже з поширеною формою захворювання.

Основну роль в лікуванні хворих на РШМ відіграють хірургічне втручання і променева терапія. Хірургічне лікування є основним на ранніх стадіях захворювання (I A-I B), тоді як променева терапія, сама по собі, або в поєднанні з операційним втручанням, широко використовуються при лікуванні місцево поширеного РШМ (II B-IV A). 5-річне виживання при використанні променевої терапії досягає 65 \% і варіює від 15 до 80 \% залежно від ступеня поширення пухлинного процесу $[4,5,6]$. Спільне застосування променевої терапії і хіміотерапії при лікуванні хворих на РШМ має ряд теоретичних обгрунтувань. Протипухлинні препарати підсилюють променеве ушкодження пухлинних клітин за рахунок порушення механізму репарації пошкодженої ДНК, синхронізації вступу пухлинних клітин у фази клітинного циклу, найбільш чутливі до променевого пошкодження, зменшення числа пухлинних клітин, що перебувають у фазі спокою, і здатності вбивати резистентні до опромінення пухлинні клітини, що перебувають в стані гіпоксії. Крім того, самі протипухлинні препарати мають цитостатичний ефект не тільки відносно первинної пухлини і регіональних метастазів, а й здатні контролювати наявні віддалені метастази. Таким чином, спільне застосування променевої терапії і хіміотерапії має підвищити протипухлинний ефект лікування хворих на РШМ $[7,8]$. Але що робити, коли звертаються пацієнтки 3 місцево поширеним РШМ, ускладненим кровотечею 3 пухлини шийки матки, з проростанням у сечовий міхур, викликаючи макрогематурію, що призводить до тяжкої ане- 


\section{ПОВІДОМЛЕННЯ}

мізації пацієнток? Зважаючи на ускладнений перебіг захворювання, загальноприйняті хірургічні тактики або хіміопроменева терапія в даній ситуації неможливі. Симптоматичне лікування? 3 огляду на вищесказане, вирішення проблеми бачиться як у поліпшенні якості діагностики, так і в удосконаленні методів лікування раку шийки матки в пізніх стадіях захворювання, особливо ускладнених кровотечею, що призводить до тяжкої анемізації пацієнток. На базі Центру реконструктивної та відновної медицини (Університетська клініка) Одеського національного медичного університету з 2011 до 2015 року при онкогінекологічної патології було виконано 81 екзентерацію таза, з них 3 приводу місцево поширеного раку шийки матки 32. 3 них 8 із тяжкою анемією на тлі кровотечі на момент госпіталізації. Тактика ведення пацієнток із місцево поширеним раком шийки матки з тяжкою анемією на тлі кровотечі з пухлини була така: тампонада піхви $\rightarrow$ підготовка до операції $\rightarrow$ лапароскопія, двобічна лімфаденектомія, кліпування внутрішніх клубових артерій або емболізація внутрішніх клубових артерій $\rightarrow$ курси поліхіміотерапії $\rightarrow$ передня тазова екзентерація.

Наводимо клінічні випадки.

1. Пацієнтка Ч., 35 років, з місцево поширеним раком шийки матки, який залучає в процес половину сечового міхура з формуванням гідроурете-

\section{СПИСОК ЛІТЕРАТУРИ}

1. Бюлетень Національного канцер-реєстру № 17 - “Рак в Україні, 2014-2015”. - С. 48-49.

2. Рак в Україні, 2008-2009. Захворюваність, смертність, показники діяльності онкологічної служби / 3. П. Федоренко, А. В. Гайсенко, Л. О. Гулак [та ін.] ; гол. ред. І. Б. Щепотін // Бюл. Нац. канцер-реєстру України. - 2010. - № 11. - 107 с.

3. Адамян Л. В. Хирургическое лечение микрокарциномы шейки матки / Л. В. Адамян, А. В. Козаченко // Медицинская кафедра. - 2005. - № 3. - С. 108-112.

4. Бохман Я. В. Рак шейки матки / Я. В. Бохман, У. К. Лютра. - Кишинев, 1993. - 220 с.

5. Доцільність хеморадіотерапії при лікуванні раку шийки матки (огляд літератури) / О. М. Сухіна, В. П. Старенький, А. В. Свинаренко [та ін.] // УРЖ. - 2011. - Т. ХІХ, вип. 1. - ронефрозу зліва, ректовагінальної нориці і тазової лімфаденопатії. Пацієнтці було виконано: підготовку до операції $\rightarrow$ лапароскопію, двобічну лімфаденектомію, кліпування внутрішніх клубових артерій, що дозволило зупинити кровотечу з пухлини шийки $\rightarrow 6$ курсів поліхіміотерапії зменшили пухлину шийки матки на $50 \% \rightarrow$ передню тазову екзентерацію з деривацією сечі за Брікером, сигмостомію. Закриття сигмостоми в плановому порядку.

2. Пацієнтка Г., 44 роки, поширений рак шийки матки 3 кровотечею $з$ пухлини, що залучає в процес сечовий міхур, викликаючи макрогематурію, двобічний гідроуретеронефроз та тазову лімфаденопатію. Пацієнтці було виконано: підготовку до операції $\rightarrow$ емболізацію внутрішніх клубових артерій, що дозволило зупинити кровотечу $\rightarrow$ 4 курси поліхіміотерапії зменшили пухлину шийки матки на $60 \% \rightarrow$ передню тазову екзентерацію 3 деривацією сечі за Брікером.

У всіх пацієнток, які пройшли лікування за вищеописаною тактикою, спостерігається безрецидивний період (3-5 років).

Висновок. Використання малоінвазивних методик, а саме лапароскопії та емболізації, є перспективним етапом лікування пацієнток з місцево поширеним раком шийки матки, що дозволяє не тільки стабілізувати онкопроцес, а й підготувати пацієнток до подальшого спеціального лікування.

\section{73-76.}

6. Кондратьева А. П. Основные направления современной лучевой терапии злокачественных опухолей / А. П. Кондратьева // Онкология. - 2003. - Т. 5, № 2. - С. 125-1

7. Thipgen T. Carcinoma of the uterine cervix: current status and future directions / T. Thipgen, R. B. Vance, T. Khansur // Semin. Oncol. - 1994. - Vol. 21(Suppl. 2). - P. 43-54.

8. Rose P. G. Locally advanced cervical carcinoma: the role of chemoradiation / P. G. Rose // Semin. Oncol. - 1994. - Vol. 21. - P. 47-53.

9. Essai randomise de chimiotherapie initiale dans 151 carcinomes du col uterin localement etendus (T2b-N1, T3b, MO) / J. Chauvergne, J. Rohart, J. F. Heron [et al.] // Bull. Cancer. 1990. - Vol. 77. - P. 1007-1024.

Отримано 02.08.16 